\section{Understanding bone fragility: theoretical explanation to non-physician health professionals}

The European League Against Rheumatism recently established timely and highly important recommendation for non-physician health professionals regarding the prevention and management of bone fractures among older adults. ${ }^{1}$ To support the health professionals' understanding of skeletal fragility, I would like to provide a theoretical explanation. ${ }^{23}$

First, non-physician health professionals are expected to play a role in the improvement of patient adherence to pharmacotherapy for osteoporosis. ${ }^{1}$ Here, it should be paid attention that the effects of osteoporosis drugs except bisphosphonates with mineral binding capacity are lost rapidly after discontinuation, ${ }^{4}$ which can be reasonably explained by functional adaptation of bone to mechanical loading during physical activity. ${ }^{3}$ Second, the homeostatic system in the skeleton ${ }^{2}$ can also explain why the small and transient effect of calcium supplementation on areal bone mineral density, measured by dual-energy X-ray absorptiometry, is lost after discontinuation. ${ }^{5}$ Finally, although vigorousintensity exercise would improve bone fragility, ${ }^{6}$ the effect can be similarly lost after discontinuation, resulting from the skeletal adaptation to mechanical environment. ${ }^{7}$ Long-term continuation of exercise should be therefore given priority over the intensity; for example, rapid bone loss following stroke ${ }^{8}$ indicates the significance of even light-intensity physical activity.

\section{Toshihiro Sugiyama $\odot$}

Correspondence to Dr Toshihiro Sugiyama, Department of Orthopaedic Surgery, Saitama Medical University, Saitama 350-0495, Japan; tsugiym@saitama-med.ac.jp

\section{Contributors TS is the sole author.}

Funding The authors have not declared a specific grant for this research from any funding agency in the public, commercial or not-for-profit sectors.

Competing interests None declared.

Patient and public involvement Patients and/or the public were not involved in the design, conduct, reporting or dissemination plans of this research.
Patient consent for publication Not required.

Provenance and peer review Not commissioned; internally peer reviewed.

(c) Author(s) (or their employer(s)) 2020. No commercial re-use. See rights and permissions. Published by BMJ.

\section{Check for updates}

To cite Sugiyama T. Ann Rheum Dis Epub ahead of print: [please include Day Month Year]. doi:10.1136/annrheumdis-2020-218003

Received 15 May 2020

Accepted 19 May 2020

\section{SLinked}

- https://doi.org/10.1136/annrheumdis-2020-218049

Ann Rheum Dis 2020;0:1. doi:10.1136/annrheumdis-2020-218003

\section{ORCID iD}

Toshihiro Sugiyama http://orcid.org/0000-0001-5551-1340

\section{REFERENCES}

1 Adams J, Wilson N, Hurkmans E, et al. 2019 EULAR points to consider for nonphysician health professionals to prevent and manage fragility fractures in adults 50 years or older. Ann Rheum Dis 2020. doi:10.1136/annrheumdis-2020-216931. [Epub ahead of print: 24 Apr 2020].

2 Sugiyama T. Vitamin D and calcium supplementation to prevent fractures in adults. Ann Intern Med 2013;159:856.

3 Sugiyama T. Treatment of low bone density or osteoporosis to prevent fractures in men and women. Ann Intern Med 2017:167:899-900.

4 Eastell R, Rosen CJ, Black DM, et al. Pharmacological management of osteoporosis in postmenopausal women: an Endocrine Society ${ }^{*}$ clinical practice guideline. J Clin Endocrinol Metab 2019;104:1595-622.

5 Willett WC, Ludwig DS. Milk and health. N Engl J Med 2020;382:644-54.

6 Sugiyama T. Physical activity and bone health: understanding mechanical strain-related stimuli. Int J Epidemio/ 2018;47:669-70.

7 Sugiyama T. Letter to the Editor: "Exercise mitigates bone loss in women with severe obesity after Roux-en-Y gastric bypass: a randomized controlled trial". J Clin Endocrinol Metab 2020;105:e989-90.

8 Sugiyama T. Letter by Sugiyama regarding article, "Screening and treatment for osteoporosis after stroke: results from the Ontario Stroke Registry. Stroke 2019;50:e307. 